\title{
Development Ecology of the Arun River Basin \\ In Nepal
}

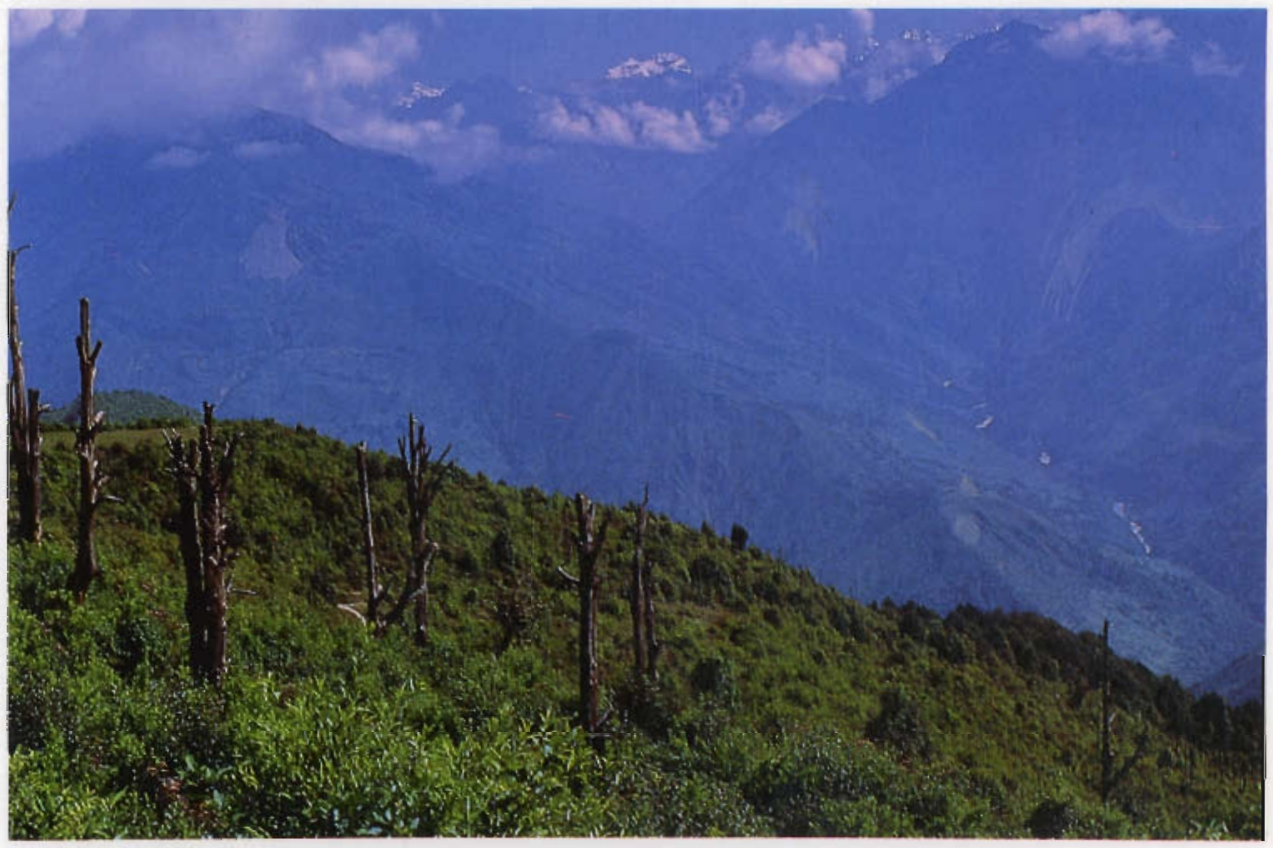

T.B. Shrestha

International Centre For Integrated Mountain Development ICIMOD

G.P.O. Box 3226

Kathmandu, Nepal 


\section{Development Ecology of the Arun River Basin In Nepal}

T.B. Shrestha

International Centre For Integrated Mountain Development ICIMOD

Kathmandu, Nepal 


\section{Copyright@1989 by the Author}

All rights resesved. No part of this book may be reproduced or transmitted in any form or by any means, electronic or mechanical, including photocopying, recording, or by any information storage or retrieval system without the prior permission in writing from the Althor.

Typeset by ICIMOD Computer Centre.

Printed by Kefford Press Ptd. Ltd., Singapore

\section{Published by}

The Intemational Centre For Integrated Mountain Development G.P.O. Box 3226, Kathmandu, Nepal

(ICIMOD Senior Fellowship Series 2)

The views and interpretation in this book are the author's and are not attributable to the International Centre for Integrated Mountain Development (ICIMOD) and do not imply the expression of any opinion concerning the legal status of any country, territory, city or area of its authorities or concerning the delimitation of the frontiers or boundaries. 


\section{Table Of Contents}

\section{Page}

Foreword $\quad$ x

Acknowledgements xiii

Summary xiv

Introduction 1

Physio-geographical Characteristics 3

Physiography 3

Nepal Himalaya 5

The Arun River Basin 8

Geology and Geomorphology 10

Major Geological Structures $\quad 12$

$\begin{array}{ll}\text { Drainage Characteristics } & 13\end{array}$

$\begin{array}{ll}\text { Slope Characteristics } & 14\end{array}$

Soil Erosion Processes 18

Climatic Features $\quad 20$

Water Resources $\quad 26$

$\begin{array}{lr}\text { Natural Vegetation And Forests } & 29\end{array}$

$\begin{array}{ll}\text { Natural Vegetation } & 29\end{array}$

Role of Eupatorium adenophorum (Banmara) 42

Biological Diversity 44 
Agricultural System

Land-use Types

Cropping Pattern

Cash Crops

58

Land Tenure System

Slash-and-burn Agriculture

Livestock, Pasture, and Fodder Situation

People And Their Natural Resources For Off-farm Employment

The People

Off-farm Activities

Forest-Based Activities

Labour-Based Activities

Mountain Tourism

Infrastructure Development And Ecology 95

Arun - III Hydroelectric Project $\quad 97$

Arun Access Road $\quad 99$

Environmental Considerations $\quad 101$

Economic Aspects $\quad 105$

$\begin{array}{ll}\text { Conclusions And Recommendations } & 107\end{array}$

Appendices

I Commercially Important Medicinal Plants in the Arun River Basin

II Birds spotted in the Arun Basin

During August/September 1986

III Fodder Plants and their Vertical Distribution 118

IV Fish which are special to Kosi System 


\section{LIST OF TABLES}

Page

Table 1 : Arun Basin Ecosystem $\quad \mathrm{xx}$

Table 2 : Sedimentation and Landslide in Kosi Catchment

Table 3 : Bioclimatic Zones in Arun Basin

Table 4 : Distribution of Land, Forests, and People by Bioclimatic Zones

Table 5 : Number of Plant Species by Climatic Zones

Table 6 : Cropped Area (in Ha, 1978/79)

Table 7 : Land Use in Various Sub-catchments

Table 8 : Area and Yield of Important Food Crops in 1970/71 And 1985/86

Table 9 : Trials of Tissue Culture Potato in the Pakhribas Agriculture Centre, Dhankuta

Table 10 : Land Revenue (in N. Rs 1000)

Table 11 : Livestock at Various Altitudes

Table 12 : Livestock Population in Khardep as Compared to Nepal (figures in thousands)

Table 13: Household population of men and mammals

Table 14 : Altitudinal Zones of Grasslands and their Succesional Types after Tsuchida 1983

Table 15 : Recommended Fodder Trees for Plantation in Arun Basin

Table 16 : Large-statured Bamboo Species

Table 17 : Small-statured Bamboos

Table 18 : Occurrence of Semi-precious and

Precious Minerals in the Arun Basin.

(courtesy : D. R. Kansakar) 


\section{LIST OF FIGURES}

Figure 1: The General Subdivision in the Himalaya

(Modified after Gansser, 1984)

Figure $2 \mathrm{~A}$ : $\quad$ Section along the Great Himalaya of Nepal, showing the dissection of the Range by rivers.

(After E.H. Pascae in Holmes, 1972)

Figure 2B : Sketch map of the Arun River Catchment showing the gorges

(After Holmes 1972)

Figure 3: $\quad$ Map of Arun Basin

Figure 4: Diagrammatic Profile of Arun Basin

Figure 5: Idealised Cross-Section across upper Arun showing typical mass wasting forms on dip and counter-dip slopes

Figure 6: Rainfall records of various stations located in Arun Basin

Figure 7: Vegetation Pattern in Nepal Himalaya

Figure 8: Bioclimatic (Altitudinal) Zonation Proposed by various Authors. (E. Nepal)

Figure 9: $\quad$ Crop Calendar in Arun Basin

Figure 9A : Proposed Extension Area of the Sagarmatha National Park

Figure 10: General Pattern of Grassland Succession

Figure 11: A Comprehensive Flow Chart of Environmental Impact due to Construction of Roads 


\section{LIST OF PLATES}

Cover picture: A sector of the Arun valley, north of Num. Burnt trees are seen on abandoned slope covered with weeds

Plate 1: A remote-sensing imagery showing the confluence of the Arun river with the Tamur and the Sun Kosi to form the Sapt Kosi that traverses the Terai plain of Nepal and goes further South to join the Ganges in India

(Courtesy of V. Galay)

Plate 2: Terracing a steep slope in the Arun Valley is a futile effort for farmers. The picture shows a steep slope (near the confluence of the Barun) under heavy human pressure and its consequences

Plate 3 : Down-cutting is very active along the Barun river. Slopes are unstable and erosion is a natural phenomenon

Plate 4: $\quad$ Leaning trees in an aldar forest (Alnus nepaleusis) indicate soil-creep on the slopes in the Kasuwa Valley, a tributary of the Arun

Plate 5: The glacial valley of Yangle (upper Barun), unlike other inner valleys of Nepal, is extremely wet. It is used as a summer pasture for yak and sheep

Plate 6: The Sabahaya khola, a southern tributary of the Arun, is quiet when it nears the confluence. Impressive Saal forest (Shorea robusta) is seen in the Valley 
Plate 7: $\quad$ The Milke-danda ridge, which separates the Arun Watershed from the Tamur, is rich in rhododendrons. Grassy slopes are interspersed with rhododendron forests

Plate 8: $\quad$ Saldima valley shows a transect of alpine and sub-alpine vegetation on its slopes. The birch forest, the fir forest and rhododendron shrubland are seen in a row of succession

Plate 9: An abandoned slope invaded by the forest weed Eupatorium after slash-and-burn cultivation. Burnt trees are seen on the fore-ground.

Plate 10: The Eupatorium gives a blanket cover to the deforested slopes

Plate 11: Rhododendron arboreum is the National Flower of Nepal (Lali Guras). Flowering period falls between March and May

Plate 12: Rhododendron cinnabarinum is one of the most beautiful shrubs at sub-alpine regions

Plate 13: The Barun Valley has virgin forests even at low altitudes. A typical mixed forest of oaks and laurels with some maple is seen at about $2,000 \mathrm{~m}$

Plate 14: $\quad$ Encroachments into the Barun Valley for growing maize. Some remnants of Saurauya trees are seen in the maize field

Plate 15: Land utilization in the Arun Watershed showing various sub-catchments 
Plate 16: $\quad$ Rhododendron trees burned by a forest fire are seen on the foreground while chestnut forests are in the background. In between, a slope abandoned after slash and burn cultivation is under natural regeneration with Eupatorium as a pioneer plant

Plate 17: Sheep herding on the Milke-danda at 3,500 m. in July and August

Plate 18: $\quad$ Goats are fed with tree fodder near Tumlingtar

Plate 19: $\quad$ Ficus auriculata is an important fodder tree which grows to $30 \mathrm{~m}$ in its natural habitat

Plate 20: $\quad$ A Navagaon lady in a "Haat Bazar" at Seduwa

Plate 21: $\quad$ Rai ladies sell "Chhyang" in the "Haat Bazar"

Plate 22: $\quad$ People of northern Sankhuwasabha are seen with bear skulls. The huge animals, that come to rob the corns in the field, are trapped to death

Plate 23: $\quad$ A Gurung shepherd collects giant rhubarb for its tender shoots which are eaten raw

Plate 24: $\quad$ The "Allo" plant (Girardinia heterophylla) grows on wastelands also

Plate 25: $\quad$ Porterage is a source of additional income for mountain people. Even young girls take part as porters in mountaineering expeditions

Plate 26: Bare-footed porters on a snowy trail to Makalu base camp

Plate 27: $\quad$ Makalu ( $8470 \mathrm{~m}$.) is the fifth highest peak of the world 
Plate 28: The Arun river as seen from Hedangna looking south. Approximate site of the Arun-III power house lies in this sector. Num village is seen at the top left hand side corner. Sub- tropical hardwood forest (Schima-Castanopsis) is seen on slopes bordering the river

Plate 29: The Arun gorge between Num and Hedangna is the approximate site for the intake of Arun-III hydro-electric project

Plate 30: $\quad$ The sector of the Arun valley lying between Chepuwa loop (Arun-IV site) and the Num loop (Arun-III site) is extremely degraded and needs special treatment for restoration. Slopes are steep, rainfall is high and the people are poor.

Plate 31: $\quad$ A sector of the Dharan-Dhankuta road showing heavy engineering work in road construction

Plate 32: Dharan-Dhankuta road extends to Vasantapur along the ridge top. New settlements appear rapidly along new roads 


\section{ABBREVIATIONS USED IN THIS REPORT/PUBLICATION}

$\mathrm{ADB}$

DFAMS

FAO

HMG

ICIMOD

JICA

KHARDEP

LRMP

PAC

UNICEF
Asian Development Bank

Department of Food and Agriculture Marketing Services

Food and Agriculture Organization

His Majesty's Government

International Centre For Integrated Mountain Development

Japan International Co-operation Agency

Kosi Hill Area Rural Development Programme

Land Resource Mapping Project

Pakhribas Agricultural Centre

United Nations International Children's Emergency Fund 


\section{Foreword}

Just over two years ago, I was particularly pleased as Director of ICIMOD to be able to announce the award of the Centre's first Senior Research Fellowship to Dr. Tirtha Bahadur Shrestha of the Royal Nepal Academy. Dr. Shrestha is already well known to his colleagues throughout the world for his many scientific publications as a Himalayan botanist and ecologist of international distinction. His arduous journeys throughout these mountains on botanical research have taken him, very much in the grand traditions of the great plant hunters of the Himalayas, to the remotest areas of this mountain Kingdom. He has fully earned the respect in which he is clearly held by the international community of Himalayan botanists. More recently, he has been a most welcome contributor to regional and international conferences on the practical scientific management of highly vulnerable, and often perilously degraded, mountain eco-systems.

His Senior Research Fellowship at ICIMOD was intended specially to enable him to pursue these broader interests in the field of development ecology. This important and most interesting monograph, for which I am privileged to write a brief Foreword, is ample evidence that he has used to the full the opportunity for expert reflection on the environmental consequences of mountain development in a specific area of Nepal. His choice of the Arun River Basin in Eastern Nepal is relevant and opportune - particularly given the large-scale investments now being undertaken by His Majesty's Government, assisted by the international aid consortium, in the Arun III Hydro-electric Project and the associated major road construction through the 
Kosi Hills. Dr. Shrestha's professional analysis of the ecology of the Arun and his careful conclusions on environmental management will doubtless be read with great interest by those concerned in both Government and the aid community.

This present monograph is being published in a new Monograph Series at ICIMOD for similar reports and studies specifically resulting from the Centre's Senior Research Fellowship Programme. With a very generous grant from the Ford Foundation, ICIMOD has been able to award similar Fellowships to eight outstanding scientists of the Hindu Kush-Himalayan Region. Each Fellowship provides the scientist concerned with a sabbatical period of research and publication on a subject of personal choice, but of direct relevance to the basic ICIMOD objective of promoting the integrated and sustainable development of mountain communities. I feel sure all will agree that this fascinating field study in Nepal by Dr. Shrestha has got this Series off to an excellent start.

Colin Rosser

Director 


\section{Acknowledgements}

I would like to extend my sincere thanks to Prof. Colin Rosser, ICIMOD Director, not only for awarding me the Senior Research Fellowship but also for his continued interest to see that my experiences and knowledge on Himalayan botany and vegetation get integrated with other professional knowledge in an effort to build up an environmental management perspective. I very much benefited from various discussions, seminars, and workshops organized by the Centre. I am indebted to a number of professional staff of ICIMOD, particularly Prof. Z. Rongsu, Prof. S.R. Chalise, Dr. Kk. Panday, Dr. T.B.S. Mahat, and Dr. H. Bista. For valuable critism and advice, I am indebted to Mr. John Dunsmore. I am very thankful to Mr. Mohan Raj and Ms. Rica Llorente for editing this work to improve its contents and style. I also wish to acknowledge the support and co-operation of Mr. Surendra Shrestha, Chief Administrator, during my period of work at ICIMOD. I am also grateful to the Secretarial and Cartographic staff of ICIMOD for their appreciable job in typing and preparing the report.

My colleagues and friends, specially Dr. P.R.Shakya (Botanist), Dr. D.R.Kansakar (Geologist), and Mr. H.S.Nepali (Ornithologist), have made their significant contribution to this work and I owe them a debt in their special field of expertise. Mr. Prabhakar Shah of the Integrated Survey Section of HMG/Nepal was extremely helpful in compiling and interpreting land use data, for which I am very grateful.

Last but not least I would also like to acknowledge the generous support of the Ford Foundation for the Senior Research Fellowship Programme at ICIMOD. 


\section{Summary}

1. The Arun Basin has a catchment area of about $36,500 \mathrm{sq} \mathrm{km}$, of which over 85 per cent lies in the Tibet autonomous region of China and an area of 5,028 sq $\mathrm{km}$, representing 14.17 per cent lies in Nepal. The $510 \mathrm{~km}$ long river carves its way through the great Himalaya and forms a dendrite type of drainage on the south of the main Himalayan range, where it travels $155 \mathrm{~km}$ in north-south alignment before merging into the Kosi system. It is an antecedent river and its downcutting has kept pace with the uplifting of the Himalaya. It has been estimated that at least $8,000 \mathrm{~m}$ of a thick rock sequence has been eroded by the river.

The range of altitudinal variation from $150 \mathrm{~m}$ to $8,470 \mathrm{~m}$ within a span of $120 \mathrm{~km}$ is typical of the eastern Himalaya. The tropical climate of the low-lying valleys gradually passes into the Temperate, the Alpine, and the Arctic climate with the progression of the altitude towards the crest of the Himalaya. Meteorological stations are few and far between. There are less than 20 stations for recording rainfall in the whole of the Arun Basin. Biological evidence supports the belief that it is one of the wettest basins in the Nepal Himalaya, with over $4,000 \mathrm{~mm}$ of annual rainfall in certain regions. The rainfall pattern is typi cal of the eastern Himalaya, where the premonsoon thunderstorms of April and May mingle with the monsoon during June, July, and August. Most of the valleys have a cloud cover above $2,000 \mathrm{~m}$, thus limiting crop cultivation. This is in great contrast to most of the catchment area lying in Tibet, where the climate is dry, cold, and arid. 
2. Slope characteristics are determined by various tectonic movements and other geological processes such as glacial, fluvial, gravity (mass movements), and the base level of erosion. The effects of climate, vegetation, and human interventions contribute to the dynamics of those slopes. The Arun Basin in Nepal may be divided into two distinct zones, i.e., the Northern and the Southern on the basis of slope characteristics, climatic conditions, and population distribution. The northern zone consists of Great Himalaya and Fore Himalaya, and the southern zone of Midlands and Mahabharat range. The Arun III hydroelectric site lies near the dividing line of those two zones.

3. Hydropower potential of the Arun river at its six sites is estimated to be of the order of 1,185 megawatts. The Arun III scheme, at a location near Num village, will have an installed capacity of 400 megawatts and is believed to be the most economical scheme among 52 hydropower schemes identified in the Sapta Kosi Basin. In an area of such high hydroelectric potential, it is essential to install a network of research and monitoring sites for developing an early warning system of hazards (natural/man-made).

4. Data on land-use vary greatly in various studies. Most landuse maps do not cover the whole country, except the ones under the Land Resource Mapping Project. According to LRMP data, major landuse types appear as following :

$\begin{array}{llrl}\text { o } & \text { Forest land (inclusive of shrub land) } & 2,538 \mathrm{~km}^{2} & (50.49 \%) \\ \text { o } & \text { Agricultural land } & 1,272 \mathrm{~km}^{2} & (25.31 \%) \\ \text { o } & \text { Grass land } & 500 \mathrm{~km}^{2} & (9.95 \%) \\ \text { o } & \text { Others (rocks, snow, water bodies) } & 716 \mathrm{~km}^{2} & (14.25 \%) \\ & \text { TOTAL } & 5,026 \mathrm{~km}^{2} & (100 \%)\end{array}$

The ratio between agricultural land and the vegetated land is of the order of 1:2. This however, varies greatly from one watershed to another. The watershed condition in the northern region is rated to be $67 \%$ excellent and $30 \%$ good, whereas in the southern-most region it is $4 \%$ excellent, $76 \%$ good, and $20 \%$ fair. Intervening midlands have $53 \%$ excellent, $47 \%$ good (Nelson 1980 ).

5. Data on soil erosion are meagre and inadequate. The annual soil erosion rate of Sapta Kosi at Chatra has been of the order of 7.8 to $36.8 \mathrm{t} / \mathrm{ha} / \mathrm{yr}$ and the annual 
denudation rate for Arun has been estimated to be $1.9 \mathrm{~mm} / \mathrm{yr}$ (Ramsay 1986). The percentage of land-slide area is estimated to be $1.16 \%$ (JICA 1985), sedimentation load is of the order of $970 \mathrm{~m}^{3} / \mathrm{yr} / \mathrm{km}^{2}$ (JICA 1986). Those figures suggest that the Arun Basin is comparatively better than the adjoining Tamur Basin in terms of soil erosion. However, a systematic study on the issue is needed both for a more realistic evaluation and for developing a monitoring system in soil erosion.

6. Biological resources in terms of genetic diversity form a unique treasure in the Himalaya, with a number of rare and endangered species. Over 3,000 species of vascular plants which include about 25 species of Rhododendron, 50 species of primroses, 45 species of orchids, 80 species of fodder trees and shrubs, 60 species of medicinal plants, and a number of wild edible plants, occur in this Basin. Besides, over 25 species of mammals, including the musk deer, tree bear, magnificent flying squirrel, water shrews, and jungle dog, occur in the wilderness of the Arun Basin. Over 200 species of birds were sighted on a 6-week trip and over 130 species were alone reported from the Barun valley. The fish fauna is rather poorly known. However, one could expect 84 species of fish, including 14 economical species for edible purposes in the waters of the Arun river. Conservation of those biological species has been attempted through designating a large part of the north-west Arun Basin as an extension area of the Sagarmatha (Mt. Everest) National Park, under the "Heart of the Himalaya" project.

7. The diversity in vegetation is exemplified by the occurrence of over 30 types of natural vegetation from Tropical Hill Sal Forest to the Alpine Grasslands. On the basis of vegetation types and corresponding altitude, 6 bioclimatic zones may be identified (Table 1). The Tropical zone corresponds to the Shorea zone, the sub-tropical to Schima-Castanopsis zone, the Temperate to Quercus zone, and the sub-alpine to Abies zone. The Alpine zone is essentially a zone of herbs and grasses. However, thickets of rhododendrons and junipers occur extensively on slopes with efficient drainage and thick soil cover.

The sub-tropical and the temperate zones have a large number of forest types, mainly dominated by oaks, chestnuts, rhododendrons, alders, and laurels. Coniferous forests are generally secondary in origin. 
Vegetation depletion, mainly through slash-and-burn agriculture, is a contributory factor in destabilization of slopes. However, a forest weed called Eupatorium adenophonm (Banmara) is aggressively colonizing all cleared slopes, thus helping to conserve soil from erosion. Information on the succession pattern from Eupatorium to original tree vegetation would provide a very useful basis for rehabilitating degraded slopes through afforestation or agroforestry. The vegetation map (Dobremez \& Shakya 1975) provides a broad framework of 'isopotential zones' for such endeavours. Stewart (1987) has produced landuse maps of existing vegetation. A combination of those two works would be a useful tool to produce a forest management plan for the Arun Basin.

8. Subsistence agriculture, with a mixed farming system, is the main economic activity in the Arun Basin. Farming systems vary greatly according to altitudinal variation. Crops are grown up to $4,000 \mathrm{~m}$ altitude, where the main crop is naked barley and potato. Those high altitude areas are used more extensively as pastures for yak, yak hybrids, sheep, and goats.

The main activities of agriculture take place at middle altitudes between $1,000 \mathrm{~m}$ and $3,000 \mathrm{~m}$. There are two basic cropping patterns : paddy-based for irrigated land, and maize-based for rain-fed land. Transhumanne is practiced at altitudes lying above the upper limit of the cropping zone (3000 $\mathrm{m}$ approx.). Livestock is an integral part of the agricultural system.

Average land holding is 0.5 ha per family and the yield has been decreasing for all the principal crops, i.e., paddy, maize, and millet. Slash-and-burn agriculture still relieves people from food deficiency. This practice is rather detrimental to the ecosystem. Therefore, a management strategy that addresses the socioeconomic problems of the mountain people has to be developed to support other developmental activities.

Three cash crops are well developed in the Arun Basin. Of these, citrus fruits, specially tangerines and sweet oranges are most developed. The southern region of the basin, specially Dhankuta and Bhojpur districts, produce large amounts of these. The marketing mechanism and storage facilities and fruit processing units are rather poorly developed. Big cardamom has recently become very 
popular as an inter-crop along alder forests. Cardamom cultivation has proved to be quite successful both economically as well as ecologically in the adjoining Tamur basin. Agronomic support and loan facilities of the HMG/Nepal have encouraged a large number of families to grow cardamom.

Potato is perhaps an important crop for the farmers of all agro-climatic regions. Production of a disease-free and high-yielding variety, through tissue culture techniques developed in Nepal, is entirely possible. However better co-ordination among various institutions is needed to ensure a regular flow of plantlets from flasks to fields.

The interdependence of crop production, livestock management, and use of forest resources is well recognized in the Arun Basin. The role of livestock as the principal source of draught power and manure is crucial in the farming system. The livestock population exceeds the human population and the pressure on forest land is on the increase. Forest areas lying between the alpine pasture land and the cultivation zone suffer greatly from double pressure of grazing from the down-coming high altitude herds (Yaks, sheep, goats) during winter and the upgoing cattle during the summer and monsoon.

All accessible grasslands are in a seminatural condition and a varying degree of succession, both retrogressive as well as progressive, is to be observed in the four different zones of grasslands. Grassland management of those zones should be based on the lessons learnt from the natural succession of plants. There are a large number of native trees and shrubs (over 75 species) that are already in use as fodder. Among them ten species, including the "gogane" (Sauraja napaulensis) and the "Nimare" (Ficus auriculata), are cultivated as village trees. Otherwise they have almost been wiped out from natural habitats.

9. People, indigenous to this basin are the "Kiratis". They are represented mainly by two ethnic groups, i.e., the Rais and Limbus. They inhabit the middle mountains. Upper reaches of the basin at higher altitudes are inhabited by Bhotea people who have a close affinity with the Sherpas and the Tibetans. Southern valleys of the basin have Brahmins, Chhetriyas, and associated occupational castes of the Hindus. Trading centres have isolated groups of Newars from Kathmandu Valley. 
A population of just over 450,000 people is distributed rather unevenly. The density per sq $\mathrm{km}$ varies from 8.2 in the sub-alpine zone to 133.44 in the sub-tropical zone. The southern district, Dhankuta, is densely populated (145.7/ sq km) while the northern district, Sankhuwasabha, is sparsely populated (37.2/ sq km). Bhojpur district (127.9/sq. km) lying in between, closely follows Dhankuta. Over $40 \%$ of the families farm at below subsistence level. They seek additional employment, such as portering, labouring on construction projects, gathering and selling medicinal herbs and firewood, preparing and selling handicrafts, quarrying semi-precious stones, and also serving in the army inside or outside Nepal.

10. Development activities in the three districts in the basin are aimed at fulfilling the basic needs of the people, by improving upon agriculture and extending education and health services; local development activities are concentrated on construction of mountain trails, suspension bridges, drinking water, irrigation schemes, and so on.

The Kosi Hill Area Rural Development Programme (KHARDEP) and the Pakhribas Agricultural Centre (PAC) have been actively engaged in a number of local development activities. The Dharan- Dhankuta Road $(51 \mathrm{~km})$ and its extension to Basantapur $(35 \mathrm{~km})$ is a major work of infrastructure development for the region.

11. The Arun III hydroelectric project (400 $\mathrm{MW}$ ) and the access road (about $70 \mathrm{~km}$ ) is regarded as priority project of HMG/Nepal, and the first phase is scheduled for completion by 1994 . This project would obviously exert a massive interference in the environment and, therefore, the utmost care should be taken during planning, construction and operational phases. Inhabitants of the Arun Basin will certainly have a special role to play in managing the environment particularly with reference to landuse and slope stability. Schemes for watershed management, nature conservation, and socioeconomic upliftment should, therefore, be an integral component of development activities of national importance. Therefore, an Action Plan for the environmentally sound management of Arun River Basin should be considered. 


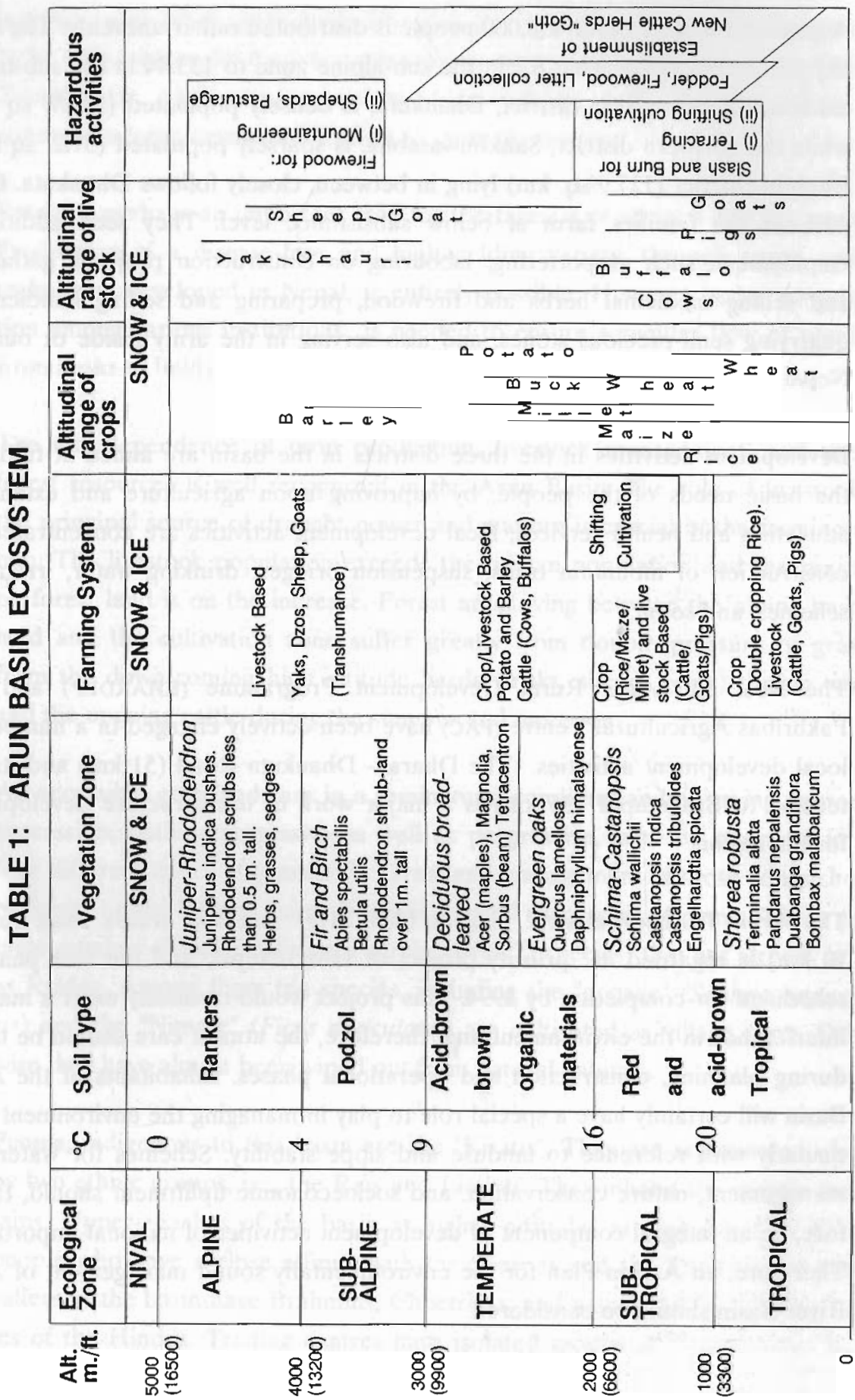

